\title{
Katarzyna Skórska
}

\section{OGRóD RODZINY FINZI-CONTINICH: historia pewnego sporu}

Pośród dziesięciu włoskich tytułów nagrodzonych Oscarem dla najlepszego filmu nieanglojęzycznego próżno szukać adaptacji filmowych. Tylko jedno z wyróżnionych dzieł powstało na motywach powieści, w dodatku powieści powszechnie znanej i cenionej. Ekranizacji podjął się nestor włoskiego kina, niemal siedemdziesięcioletni Vittorio De Sica, a w pracy nad scenariuszem uczestniczył sam autor książki - Giorgio Bassani. Film OGRóD RODZINY Finzi-Continich (Il giardino dei Finzi-Contini, 1970), zatytułowany tak samo jak jego literacki pierwowzór, miał wszelkie dane ku temu, by przejść do historii kinematografii nie tylko włoskiej, lecz i światowej. Przyznana w 1971 roku nagroda Amerykańskiej Akademii Filmowej - poparta Złotym Niedźwiedziem w Berlinie, który ugruntował pozycję filmu na rynku europejskim - z pewnością taki status gwarantuje. Nie obyło się jednak bez skandalu. Otóż pisarz postanowił na drodze prawnej wycofać swoje nazwisko z czołówki. Rzecz nie bez precedensu w przypadku adaptacji prozy, lecz jeśli przypomnieć, że związki Bassaniego z kinem nie ograniczały się jedynie do prac nad tym właśnie filmem ${ }^{1}$, działanie autora powieści należy uznać za coś więcej niż kaprys, czy wynik braku porozumienia dwóch wielkich indywidualności dwudziestowiecznej włoskiej

${ }^{1}$ Pisarz współpracował m.in. przy scenariuszu ZwYCiĘżonYCH (I vinti) Michelangela Antonioniego z 1953 roku, był jednym ze współscenarzystów nakręconych w 1954 ZmysŁów (Senso) Luchina Viscontiego, jak również użyczył swojego głosu postaci reżysera kreowanej przez Orsona Wellesa w noweli Piera Paola Pasoliniego TwARóG (La ricotta), wchodzącej w skład filmu RoGoPAG z 1963 roku. 
sceny artystycznej. Zarzewiem konfliktu stała się oto postać Giorgia, głównego bohatera tej osnutej w pewnej mierze na wątkach autobiograficznych opowieści Bassaniego.

Powieść Ogród rodziny Finzi-Continich wchodzi w skład sześciotomowego cyklu Il romanzo di Ferrara (Powieść ferraryjska ${ }^{2}$ ) i stanowi z pewnością jego część najbardziej znaną i poczytną, w mikrokosmosie dwudziestowiecznej literatury włoskiej wynosząc Ferrarę do rangi Proustowskiego Combray czy Dublina Joyce'a. Opowiedziana $\mathrm{w}$ pierwszej osobie historia przedstawia losy grupy dwudziestolatków, studentów głównie pochodzenia żydowskiego, w przededniu wybuchu II wojny światowej. Bezimienny narrator wspomina dom i tytułowy ogród Finzi-Continich, fikcyjnej rodziny żydowskiej, która odseparowana od reszty ferraryjskiej społeczności żyła w zaciszu Barchetto del Duca - rozległej posiadłości otoczonej wysokim murem, wzbudzając duże emocje, zaciekawienie, fascynację, a czasem nawet zawiść wśród lokalnych mieszkańców. Z Micòl i Alberto oraz ich ojcem, profesorem Ermanno, głównego bohatera łączą szczególne więzi: znajomość z okresu dorastania przeradzająca się z czasem w przyjaźń intelektualną, a w przypadku Micòl - w niespełnione uczucie.

\section{Bassani kontra De Sica}

Wydana w 1962 roku książka odniosła we Włoszech ogromny sukces tak wśród czytelników, jak i krytyki, zdobywając Premio Viareggio, jedną z najbardziej prestiżowych, zwłaszcza w owym czasie, nagród literackich. Doczekała się wielu przekładów, w tym polskiego, wydanego niemal równocześnie z oryginałem w 1964 roku. We Włoszech od razu pomyślano też o ekranizacji, bo książka zdawała się stanowić znakomity materiał filmowy. Prawa do powieści nabyła spółka Documento Film, a do prac nad scenariuszem zatrud-

${ }^{2}$ Zob. więcej w: Historia literatury włoskiej XX wieku, red. Joanna Ugniewska, Warszawa: Wydawnictwo Naukowe PWN 2001, s. 255-259. 
niono Valeria Zurliniego, który miał dzieło wyreżyserować, oraz scenarzystę Salvatore Lauraniego. Bassaniemu pierwsze efekty ich prac nie przypadły do gustu - pisarz zarzucał duetowi autorów, że zanadto czerpali oni z jego dotychczasowego dorobku pisarskiego, miast skupić się tylko na tej jednej powieści ${ }^{3}$. W kolejnych latach do zmagań ze scenariuszem przystępowali inni twórcy, do czasu, gdy w 1966 roku Zurlini postanowił się wycofać. Z początkiem 1970 roku Documento Film przekazała projekt Vittorio De Sice, a prace nad scenariuszem powierzono samemu pisarzowi we współpracy z Vittorio Bonicellim (współautorem scenariusza m.in. BARBARELLI Rogera Vadima). Ów duet uporał się z opracowaniem istniejącego już częściowo materiału zaledwie w dwa tygodnie. Bassani, przekazując scenariusz Gianniemu Hechtowi z firmy Documento Film, wyraził dwa życzenia. Pierwsze z nich było dość oczywiste, zwłaszcza w przypadku literata - mianowicie, po naniesionych uwagach technicznych, uwarunkowanych potrzebami ekranizacji, Bassani chciał mieć możliwość wglądu w ostateczną wersję scenariusza i dokonania ewentualnych poprawek autorskich. Druga prośba dotyczyła z kolei zamieszczenia $\mathrm{w}$ filmie czarno-białych zdjęć przedstawiających masowe zatrzymania Żydów po 8 września 1943 roku, których świadkiem miał być główny bohater. Żadne z tych życzeń nie zostało jednak spełnione. Scenariusz zwrócono Bassaniemu w momencie, gdy zdjęcia do filmu już się rozpoczęły. Przeróbek w tekście dokonał uznany scenarzysta i stały współpracownik Documento Film - Ugo Pirro ${ }^{5}$. Najpoważniejszą zmianą było włączenie do grupy

${ }^{3}$ Szczegółowe dzieje scenariusza filmu znajdziemy we wstępie poprzedzającym wywiad z Ugo Pirrem, opublikowany w opiniotwórczym w owym czasie tygodniku „L'Europeo”. Enzo Magrì, Cinema contro letteratura, „L'Europeo”, 28.01.1971, s. 76-81.

${ }^{4}$ Data odezwy marszałka Pietra Badoglia do narodu, w której ogłosił rozejm z wojskami aliantów. Reakcja Niemiec była natychmiastowa: siły Wehrmachtu wkroczyły do północnych Włoch. Wkrótce potem zaczęto aresztować Żydów i wywozić ich do Auschwitz-Birkenau.

${ }^{5}$ Por. Enzo Magrì, op. cit., s. 77. 
pojmanych w finale Żydów (w tym i Finzi-Continich) ojca głównego bohatera, przy jednoczesnej rezygnacji z użycia zaproponowanych przez Bassaniego czarno-białych zdjęć. Autor Powieści ferraryjskiej, będąc przekonany, że film zostanie nakręcony według jego wersji scenariusza, pozwolił, aby jeden z obiektów zdjęciowych stanowił bardzo charakterystyczny dom w Ferrarze, od lat należący do jego rodziny. Tym samym utożsamienie filmowego bohatera z samym Bassanim stało się właściwie nieodparte, zważywszy, że w filmie nosi on imię Giorgio, choć, jak wspominałam, w powieści imię to ani razu nie pada. Autor zaś na taki stan rzeczy zgodzić się nie mógł, gdyż jego zdaniem filmowy Giorgio igra z losem swojego ojca, którego pisarz, jak wielokrotnie podkreślał, bardzo kochał.

Zarzuty wobec filmowej wersji Ogrodu rodziny Finzi-Continich właściwie były trzy i zadecydowały o skierowaniu sprawy do sądu. Bassani zawarł je wszystkie w szkicu zatytułowanym Il giardino tradito (Zdradzony ogród), zamieszczonym później w tomie esejów Di là dal cuore (Po tamtej stronie serca). Pierwszy zarzut dotyczył właśnie owego

(...) posłużenia się moim domem w Ferrarze, w celu mocniejszego powiązania z moją osobą historii, która wcale mnie nie dotyczyła, ukazania mnie jako człowieka zdolnego igrać z życiem i śmiercią osoby, którą najbardziej ukochałem w świecie, czyli mojego ojca: oto dwa dość poważne nadużycia, których próbowano się względem mnie dopuścić. Jeśli zniósłbym je bez protestów, nie mógłbym mianować się pisarzem, czy nawet po prostu człowiekiem ${ }^{6}$.

Drugi zarzut Bassaniego skupiał się na pominięciu jego wyraźnej prośby:

Zabieg narracyjny użycia nawracających czarno-białych zdjęć uznawałem za konieczny z wielu powodów. Po pierwsze dlatego, że w jakiś sposób byłby w stanie oddać strukturę powieści, której akcja, jak wiadomo, rozgrywa się na dwóch różnych planach czasowych: teraźniejszym (początkowa wycieczka do Cerveteri,

${ }^{6}$ Giorgio Bassani, Il giardino tradito, [w:] Di là dal cuore, Mediolan: Mondadori 1984, s. 321 (tłum. K. S.). 
przypadająca na pewne niedzielne popołudnie w kwietniu 1957 roku) i przeszłym (lata 1938-39); lecz nade wszystko dlatego, że pozwoliłby uniknąć płaskiej, nużącej dosłowności i uproszczeń rodem z komiksu?

\section{Stąd właśnie wynika trzeci z zarzutów:}

Akcja nowego scenariusza, naszpikowana całkowicie obcymi duchowi powieści uproszczeniami, rozgrywała się oto na jednym planie czasowym, czyli w przeszłości: efektem tego, poza wszystkim innym, było zubożenie postaci Giorgia, głównego bohatera, i spowodowanie, że jego znaczenie stało się znikome czy wręcz żadne. Tym samym opowiedziana historia stawała się banalna, sentymentalna, po prostu nijaka, do tego stopnia, że można by zadawać sobie pytanie, dlaczego właściwie poświęcono jej długometrażowy film ${ }^{8}$.

Wytwórnia filmowa Documento Film oraz reżyser Vittorio De Sica uznali te oskarżenia za bezpodstawne ${ }^{9}$. Złożywszy sprawę w sądzie ${ }^{10}$, Bassani domagał się, aby podano do publicznej wiadomości, że to nie on jest autorem wykorzystanego scenariusza oraz by wstrzymano dystrybucję filmu, albo przynajmniej wyraźnie zaznaczono, jak bardzo wersja kinowa różni się od literackiego pierwowzoru. Formalnie sprawa zakończyła się zakazem umieszczenia nazwiska Bassaniego w napisach czołowych filmu oraz nakazem podania w nich informacji, że dzieło jest „swobodnie oparte na motywach powieści Giorgia Bassaniego"11. Tak też się stało, a scenariusz ostatecznie podpisali Ugo Pirro i Vittorio Bonicelli. „Jestem autorem powieści. Nie jestem, choćby nawet po części, współautorem

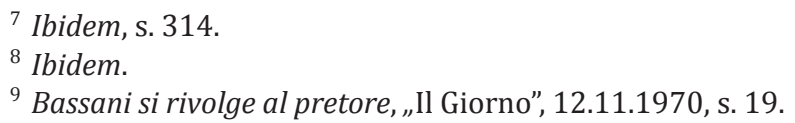

${ }^{7}$ Ibidem, s. 314.

${ }^{8}$ Ibidem.

${ }^{9}$ Bassani si rivolge al pretore, „Il Giorno”, 12.11.1970, s. 19.

10 Dokładne sformułowanie zarzutów znajdziemy w krótkiej notce informacyjnej: Bassani si rivolge al pretore, „Il Giorno”, 12.11.1970: „Autor twierdzi, iż film wynaturza wymowę jego dzieła, a on sam nie rozpoznaje się w tak ukazanej historii. Ponadto uważa, że producent nie ma prawa umieścić jego nazwiska pośród scenarzystów, bo pierwotny scenariusz został całkowicie zmieniony, a film pogwałca jego osobiste dobro" (tłum. K. S.).

${ }^{11}$ Bassani torna sul film contestato, „Il Giorno”, 25.11.1970, s. 19. 
filmu. Sądzę, że każdy sędzia przyzna mi rację" ${ }^{\prime 2}$, konkludował Bassani w wydanym publicznie oświadczeniu.

Cały spór, rzecz jasna, odbił się echem również na łamach prasy. Prócz bieżących wzmianek w dziennikach, obie strony udzielały obszernych wywiadów, nie unikając wzajemnych docinków czy wręcz inwektyw (Bassani określił Pirra chałturnikiem, ten zaś nie pozostał mu dłużny, wytykając adwersarzowi pychę, histerię, zatracenie proporcji, prowincjonalizm, a nawet kompleks Żyda ocalałego z zagłady), które zaowocowały żądaniami odszkodowania i wzajemnymi skargami o zniesławienie ${ }^{13}$. Rzeczywiście kinowa wersja Ogrodu rodziny Finzi-Continich nie unika uproszczeń, a zarzuty ze strony krytyki włoskiej ${ }^{14}$ i samego Bassaniego o schlebianie gustom masowej widowni nie wydają się całkiem bezzasadne. Film odniósł, tak czy owak, spory sukces w Stanach Zjednoczonych; prócz wspomnianej nagrody Akademii dla najlepszego filmu nieanglojęzycznego uzyskał także nominację w kategorii najlepszy scenariusz adaptowany (tryumfował wówczas FRANCUSKI ŁĄCZNIK [The French Connection] w reżyserii Williama Friedkina), co wielu, szczególnie zaś czytelnikom powieści, może wydać się zastanawiające. Problem mianowicie polega na tym, że film ów nie tyle odbiega od oryginału,

12 Ibidem (tłum. K. S.).

${ }^{13}$ Nawet po blisko czterdziestu latach Ugo Pirro niechętnie wracał do tematu filmu, nie mając raczej dobrych wspomnień z tego epizodu swojej kariery - w wywiadzie, udzielonym Manuelowi De Sice i zarejestrowanym na potrzeby wydania płyty DVD z filmem OGRód RODZINY FINZI-CoNTINICH w serii Il grande cinema, jedynie na początku i dość pobieżnie przywołuje dzieje konfliktu, by chwilę potem przejść do opowieści o swojej dalszej współpracy z De Siką i ciepłych anegdot o reżyserze.

${ }^{14}$ Zarzutów ze strony włoskiej krytyki było zresztą więcej, o niektórych z nich wspomina Tadeusz Miczka: „Patos i dostojeństwo, z jakim ukazane zostało na ekranie środowisko zamożnej rodziny żydowskiej w latach 40., stały się jednak dla niektórych włoskich krytyków pretekstem do formułowania ostrych zarzutów pod adresem reżysera. Irytował ich staroświecki styl narracji i kompozycji kadrów, drażniła ich jego »nekrologiczna« wymowa". Tadeusz Miczka, W Cinecittà i okolicach, Kraków: Oficyna Literacka 1993, s. 215-216. 
co znacznie go wypacza. Zwłaszcza że kilka rozwiązań dramaturgicznych (choćby nienaturalnie pospieszne i zdawkowe podanie w dialogu informacji o śmierci Malnatego na froncie wschodnim w 1941 roku), pewne niespójności charakterologiczne w rysunku postaci (szczególnie, gdy w ich ustach pojawiają się partie dialogowe żywcem wzięte z powieści) zdają się bezsprzecznie wskazywać na to, iż scenariusz przechodził z rąk do rąk i był wielokrotnie poprawiany. W tym świetle zastanawiający wydaje się też czas trwania filmu - dziewięćdziesiąt minut - dość krótki jak na tak obsadzoną międzynarodową produkcję długometrażową z początku lat siedemdziesiątych (dzieło w napisach czołowych określono jako koprodukcję włosko-niemiecką).

\section{Micòl i chłopcy}

Vittorio De Sica postanowił rozpocząć ekranizację powieści od sceny przed bramą tytułowego ogrodu - spotkania kilkorga studentów, którzy w większości zostali wykluczeni z miejskiego Klubu Tenisowego im. Eleonory d'Este ze względu na żydowskie pochodzenie, zgodnie z wprowadzonymi we Włoszech w końcu września 1938 roku ustawami rasowymi. Reżyser zrezygnował tym samym z jakże filmowej, wydawać by się mogło, współczesnej ramy czasowej zastosowanej przez Bassaniego w powieści, rozpiętej między prologiem, ukazującym wycieczkę do etruskich grobów w Cerveteri, która przywołała w autorze przedwojenne wspomnienia i tym samym przyczyniła się do napisania dzieła, a epilogiem objaśniającym wojenne losy bohaterów. W ten sposób film stracił niezwykle oryginalny walor swojej książkowej wersji, jakim jest podanie do wiadomości czytelników już na pierwszych stronach powieści, że wszyscy najważniejsi jej bohaterowie nie żyją. U Bassaniego podróż do świata zmarłych Etrusków staje się początkiem podróży do świata zmarłych Finzi-Continich, wędrówki do świata widm; 
z planu teraźniejszego przenosimy się w przeszłość. U De Siki z kolei mamy do czynienia z narracją wzbogaconą o cztery retrospekcje, o których dokręceniu zadecydowano zresztą na etapie prac montażowych ${ }^{15}$, ukazujące nastoletnich Giorgia i Micòl. Sam film zaś otwiera lakoniczny napis „Ferrara 1938-1943” w dość osobliwy sposób zamykający fabułę filmu w odgórnie ujawnionym przedziale czasu. Oczywiście scena spotkania przy grze w tenisa to doskonały punkt wyjściowy do ekspozycji postaci, jednak w stosunku do swoich literackich pierwowzorów i te wiele straciły. Należy przyznać De Sice, że znakomicie obsadził ojca Giorgia - kreowanego przez Romola Vallego - oraz parę tytułowych bohaterów. Właściwie trudno sobie wyobrazić inną Micòl niż tę, której swoje rysy dała Francuzka Dominique Sanda, jedna z najpiękniejszych młodych aktorek owego okresu, ciesząca się wtedy ogromną popularnością (zaledwie rok wcześniej zadebiutowała tytułową rolą w ŁAGODNEJ [Une femme douce, 1969] Roberta Bressona, a w tym samym czasie, co w OGRodzie Rodziny FInZI-Continich, wystąpiła także w KonFORMIŚCIE [Il conformista] Bernarda Bertolucciego). Niestety, mimo że trudno cokolwiek zarzucić kreacji Sandy, w ujęciu scenarzysty z intrygującej, żyjącej przeszłością, inteligentnej młodej kobiety, przeczuwającej nieuchronną i bliską śmierć, Micòl przemienia się w rozkapryszoną panienkę z dobrego domu - próżną, nieco znudzoną manipulantkę o melancholijnym wejrzeniu; z kolei jej młodzieńcza niekonsekwencja przeistoczyła się na ekranie w zwykłe zepsucie. Przeczucie śmierci w przypadku filmowej Micòl przeradza się w pełne rezygnacji, puste gry miłosne prowadzone $\mathrm{z}$ adoratorami, do których sama nie jest przekonana, zdając sobie sprawę z ich błahości i bliskiego kresu. Powieściową Micòl śmiało można określić jako jedną z najciekawszych i najbardziej złożonych psychologicznie postaci kobiecych włoskiej literatury powojennej. Badaczka literatury Monica Farnetti w szkicu poświęconym bohaterce

15 Jak ujawniają Ugo Pirro i Manuel De Sica w wywiadzie dołączonym do wydania DVD filmu OGRód RoDZINY FINZI-ConTINICH w serii Il grande cinema. 
zauważa, że w zebranej i wydanej przez towarzyszkę życia pisarza, Portię Prebys, obszernej bibliografii ${ }^{16}$, Micòl nieprzypadkowo poświęcono najwięcej, bo ponad cztery tysiące pozycji; w plebiscycie rozpisanym z kolei przez literacki dodatek dziennika „La Stampa” zajęła ona - z pewnością dyskusyjne, lecz warte odnotowania pierwsze miejsce, jako najbardziej fascynująca bohaterka kobieca wszech czasów ${ }^{17}$. Pisał o niej sam Bassani: „Micòl chce jedynie być inna, chce żyć, w pewnym sensie to ona niesie moje przesłanie"18. Jak zauważa Gianni Venturi, znakomity badacz twórczości ferraryjskiego pisarza, życie, które Micòl z tak wielkim zapałem próbuje pochwycić w przeszłości i wiecznej teraźniejszości, a które mimo wszystko odrzuca, to ciągły temat rozważań Bassaniego nad własnym dziełem ${ }^{19}$. W interpretacji De Siki i Pirra z kolei Micòl zdaje się zupełnie oderwana od życia, odległa, jakby reżyser celowo ustawił ją za tak typową dla poetyki Bassaniego - w tym przypadku niewidzialną - szybą. Stąd bezwzględność i chłód bohaterki, które w powieści rodzą się z uświadomionego smutku, w filmie zaś zdają się mniej umotywowane. Paradoksalnie, filmowa Micòl staje się najbliższa tej powieściowej w scenie nieobecnej w książce, w finale ekranizacji, w którym ukazano aresztowanie i rozdzielenie członków rodziny Finzi-Continich przed ich deportacją do obozu, czyli gdy bliskość śmierci jest już niezaprzeczalna. W filmie „brak jakiejkolwiek projekcji, subiektywizacji tego poczucia przeszłości i śmierci sprawiających, że postaci Micòl nie da się zapomnieć"20, pisał na

${ }^{16}$ Portia Prebys, Giorgio Bassani: bibliografia sulle opere e sulla vita, Florencja: Centro Editoriale Toscano 2002.

${ }^{17}$ Monica Farnetti, Il tema di Micel, [w:] Ritorno al „Giardino”. Una giornata di studi per Giorgio Bassani, red. Anna Dolfi, Gianni Venturi, Rzym: Bulzoni Editore 2006, s. 111.

18 Giorgio Bassani, In risposta VI, [w:] Opere, wstęp i red. Roberto Cotroneo, Mediolan: Mondadori 1998, s. 1326 (tłum. K. S).

${ }^{19}$ Gianni Venturi, Dimenticare Euridice, [w:] Ritorno al „Giardino”..., s. 95-96.

${ }^{20}$ Gian Battista Cavallaro, De Sica e Bassani: Incontro all'italiana, „Il Dramma” 1971, t. XLVII (1-2), s. 74 (tłum. K. S). 
łamach „Il Dramma” Gian Battista Cavallaro. W ekranizacji dochodzi do umniejszenia wagi jednej z najistotniejszych kwestii wypowiadanych przez Micòl w literackim pierwowzorze, w której tak oto tłumaczy ona Giorgiowi, dlaczego ich miłość jest niemożliwa:

(...) wyjaśniła, że ja, podobnie jak i ona, nie mam wrodzonego instynktu posiadania czegoś, instynktu, który cechuje ludzi normalnych. (...) dla mnie tak samo jak dla niej, większą ma wartość pamięć o pewnych rzeczach aniżeli ich posiadanie, pamięć, wobec której posiadanie samo w sobie jest brzemienne w rozczarowania, banalne i rozczarowujące. Jakże ona mnie rozumie! Moje pragnienie, żeby chwila obecna stała się natychmiast przeszłością, po to, żebym mógł ją kochać i marzyć o niej do woli, jest jej dobrze znane, bo i ona odczuwa to samo. To już taki nasz nałóg - kroczyć naprzód z twarzą wciąż zwróconą za siebie. Czyż nie tak jest ze mną? Owszem, tak było, musiałem przyznać w głębi duszy, że tak właśnie było ze mną ${ }^{21}$.

Twórcy filmu, rezygnując z jakiegokolwiek potwierdzenia, że Giorgio całkowicie zgadza się ze słowami Micòl, sprawili, że rzeczywiście zasadne wydaje się podejrzenie bohatera, iż odtrącenie jego uczuć ma bardzo prozaiczną przyczynę, a mianowicie, że zwyczajnie nie pociąga on fizycznie swojej ukochanej. Trudno więc nie zgodzić się z Bassanim, że tak ukazana historia staje się po prostu banalna. Podobnie powierzchowna zdaje się postać śmiertelnie chorego Alberta, kreowana przez Helmuta Bergera. Choć aktor odbiega wyglądem fizycznym od powieściowego pierwowzoru, to jego wybór do tej właśnie roli należy uznać za nader trafny. Przekonująco gra w scenach z Sandą, zdających nie kończyć się chwilach spędzanych przy muzyce jazzowej czy przy korcie tenisowym w ogrodzie. Berger wypada natomiast gorzej, gdy partneruje mu Fabio Testi, filmowy Giampi Malnate, jedyny w tym kwartecie goj, przyjaciel Alberta z czasów studenckich. W powieści Malnate to zapalczywy komunista i poglądowy antagonista głównego bohatera. Przez Bassaniego został on ukazany jako dość burkliwy, ale bystry i doświadczony, masywny okularnik. Malnate wywodzi się

${ }^{21}$ Giorgio Bassani, Ogród rodziny Finzi-Continich, tłum. Barbara Sieroszewska, Warszawa: Państwowy Instytut Wydawniczy 1964, s. 242. 
niechybnie z proletariatu, jednak z pewnością nie jest on, jak ukazał go De Sica, typem muskularnego troglodyty, czy prężącego swe ciało sportowca rodem z TRYUMFU woli (Triumph des Willens, 1943) Leni Riefenstahl. Kiedy Micel, przedstawiając Malnatego Giorgiowi, mówi, że pracuje on w przemysłowej strefie Ferrary, widz nie dopatrzy się raczej w jego osobie zdolnego inżyniera chemii, miłośnika romantycznej poezji dialektalnej. Zresztą to właśnie konstrukcja jego postaci jest najbardziej niekonsekwentna, jako przykład niech posłuży scena, gdy niczym uczniaka krytykuje Giorgia za jego prowokacyjne zachowanie w kinie (kalumnie, jakie ten wykrzyczał w stronę ekranu, na którym wyświetlana była kronika filmowa), co zupełnie nie koreluje z dotychczas wygłaszanymi przezeń dość prostymi, niezgrabnymi uwagami i sądami. Wybór Testiego, który do czasu występu w filmie De Siki wsławił się głównie rolami w spaghetti westernach, przy czym niemal zawsze głosu na ekranie użyczał mu ktoś inny, to z pewnością najbardziej dyskusyjna decyzja reżysera. Osobne słowo należy się rzecz jasna Giorgiowi, kreowanemu przez Lina Capolicchia, aktora zespołu mediolańskiego Piccolo Teatro Strehlera. Rzecz w tym przypadku jest o tyle ciekawa, że Bassani był wykładowcą Capolicchia podczas jego studiów w Szkole Teatralnej. Aktor wspominał go po latach jako surowego nauczyciela, podobnie zresztą jak De Sikę. W swojej kreacji, uhonorowanej nagrodą Davida di Donatello, Capolicchio może momentami jest zanadto choleryczny i obdarzony nazbyt dużą inicjatywą (bohater Bassaniego jest raczej bierny i flegmatyczny), co może drażnić, lecz jak stwierdził w jednym z wywiadów sam aktor, pisarz podczas prywatnej rozmowy wyznał $\mathrm{mu}$, że cieszy się z jego wyboru do tej właśnie roli ${ }^{22}$.

W filmie De Siki wszystko uległo niejakiemu przerysowaniu w stosunku do oryginału; bohaterowie są bardziej wyemancypowani, śmielsi, odznaczają się większą pewnością siebie, ich sylwetki cechuje pewna dosadność przejawiająca się w zbyt dosłownym obrazowaniu

${ }^{22}$ Wywiad z Linem Capolicchiem przeprowadzony przez Manuela De Sikę, zamieszczony w dodatkach do wydania DVD filmu OGRóD RODZINY FINZI-ConTINICH w serii Il grande cinema. 
łączących ich relacji. Napięcie w owym uczuciowym deblu MicòlGiorgio - Malnate-Alberto budowane jest głównie poprzez stanowcze podkreślanie w zbliżeniach (gra spojrzeń, gesty) i detalach (dłonie) istniejącego między bohaterami napięcia erotycznego (nawet ocierającej się o kazirodztwo nadmiernej bliskości rodzeństwa). Stąd Alberto wydaje się momentami zbyt oczywisty w swoim homoseksualizmie i fizycznej fascynacji Malnatem (w powieści zaznaczonej jedynie poprzez aluzje); Micòl przeradza się w wyrachowaną intrygantkę, z której dopiero aresztowanie i rozdzielenie członków rodziny wykrzesają odrobinę ciepła; Giampi przybiera posągowe kształty, a Giorgio może irytować swoim napuszeniem. Subtelne cechy bohaterów ulegają wykrzywieniu w filmowym zwierciadle De Siki. Ta dosłowność znajduje swoje apogeum w wieńczącej historię miłosną scenie, w której Giorgio pod osłoną nocy przeprawia się przez mur ogrodu i w domku letnim, zwanym z niemiecka Hütte, patrząc przez szybę, nakrywa kochanków - półnagą Micòl, która jakby od niechcenia, a zarazem z okrutną ostentacją zapala światło, i śpiącego obok niej Malnatego. To ostatnia scena właściwej części powieści, opisana przez Bassaniego tak, że czytelnik nie wie, czy stało się to naprawdę, czy też wszystko zrodziło się w opętanym zazdrością i pogrążonym w rozpaczy po stracie ukochanej umyśle bohatera. Potwierdzenie tej ambiwalencji pojawia się zresztą w epilogu dzieła, w którym autor umieszcza komentarz: „Co właściwie było między nimi dwojgiem? Nic? Któż to wie!”23 Niestety, $\mathrm{w}$ filmie kolejny raz, wbrew Bassaniemu, ważniejsze stało się to, co „zaszło” niż to, co „nie zaszło” między bohaterami.

\section{Po tamtej stronie muru}

Ogród, choć w rzeczywistości nieistniejący - zdjęcia kręcono $\mathrm{w}$ różnych parkach włoskich, m.in. w Rzymie, w ogrodzie botanicznym oraz w Villa Ada, jak również w Villa Reale w Monzy, a jedynie

${ }^{23}$ Giorgio Bassani, Ogród rodziny..., s. 317. 
prowadząca doń brama uwieczniona w filmie znajduje się w Ferrarze - to miejsce, w którym chronią się przed ludźmi i bezlitosną przyszłością członkowie rodziny Finzi-Continich, „dalecy i niedosiężni - jak gdyby jakaś szklana ściana dzieliła ich od otaczającego świata"24. Posiadłość opasuje wysoki mur, wpisujący przestrzeń powieści we wspominaną przez Gastona Bachelarda dialektykę wnętrza i zewnętrza, filozoficzne bycie i nie-bycie ${ }^{25}$. Prawdopodobnie najbardziej zasłużona badaczka twórczości Giorgia Bassaniego, Anna Dolfi, przystępując do analizy zjawiska melancholii w jego cyklu powieściowym, mówi o elementach diafragmatycznych, zaliczając do nich również czas $^{26}$. Zaparowane szyby, mur ogrodu, labirynt domu, nazywanego magna domus, metalowa siatka kortu tenisowego, przeszklone drzwi, mury miasta, zbierane przez Micòl weneckie mleczne szkła zwane lattimi - każde z nich wyznacza granice, mniej lub bardziej wyraźne, określa dystans, z jakiego można obserwować, ustawia optykę narratora i czytelnika. Jak pisze dalej Dolfi:

(...) wszyscy intra muros tej samej synagogi przy via Mazzini, zebrani pod tałesem, w czasie berachy (...) młody bohater i Finzi-Contini w rzeczywistości są podzieleni i wzajemnie sobie odlegli. Jeśli inni to zazwyczaj nie-Żydzi, tutaj inni są również Finzi-Contini, odseparowani w swoim ogrodzie, położonym pośród miejskich murów ${ }^{27}$.

W filmie, owszem, tę „inność”, odosobnienie i wyniosłość Micòl i Alberta uchwycić się udało. Z pewnością jednak nie do końca powiodło się owo zamykanie przestrzeni, wyznaczanie granic za pomocą środków scenograficznych, choć należy zauważyć, że u De Siki podobnie jak u Bassaniego dużo jest szyb stanowiących filtr,

24 Ibidem, s. 43.

25 Gaston Bachelard, La poetica dello spazio, Bari: Edizioni Dedalo 1999, s. 233.

${ }^{26}$ Anna Dolfi, Giorgio Bassani: una scrittura della malinconia, Rzym: Bulzoni Editore 2003, s. 11.

27 Ibidem, s. 34-35. 
przez który bohaterowie spoglądają na świat (m.in. Giorgio nakrywa przez nią kochanków, Micòl w finałowej scenie rzuca przez szybę pożegnalne spojrzenie na Ferrarę). Reżyser całkiem zrezygnował natomiast z wprowadzenia lattimi, którymi Micòl jeszcze bardziej odgradzała się od świata, choć, jak w monografii poświęconej związkom pisarza z kinem twierdzi Federica Villa, poprzez zabiegi operatorskie zastosowane przez Ennia Guarnieriego, takie jak użycie światła rozproszonego, osiągnięcie efektu miękkości dzięki niedoostrzeniom i filtrom, widz czuje się niejako uwięziony wraz $\mathrm{z}$ bohaterami $\mathrm{w}$ takowym lattimo ${ }^{28}$. Jeśli zaś chodzi o filmowy mur, to łatwość, z jaką Giorgio go pokonuje, oraz to, że w wymyślonej przez twórców filmu dodatkowej scenie wspina się nań, by podglądać grających na korcie, zupełnie rujnuje zamysł pisarza, który w powieści uczynił zeń niedającą się przestąpić granicę. Jej przekroczenie wymaga od bohatera stanowczej decyzji, pokonania w sobie owego Celestyna, jak nazwała go niegdyś Micòl, nie tylko ze względu na kolor jego oczu (włoskie celeste to określenie barwy niebieskiej), ale nawiązując również do papieża Celestyna V i jego słynnej abdykacji ${ }^{29}$. U Bassaniego scena przekroczenia muru pojawia się dwukrotnie. Raz dzieje się to w dzieciństwie, gdy nakłaniany przez Micòl chłopiec początkowo wymawia się, odczuwając nieokreślony lęk, a gdy wreszcie ukrywa rower, by móc swobodnie przedostać się na drugą stronę, jest już za późno - Micòl znika upomniana przez stróża Perottiego. Jak wspominałam, do ponownego przekroczenia muru w tym samym co dziesięć lat wcześniej miejscu, tym razem udanego, dochodzi w zakończeniu powieści, gdy udręczony tęsknotą „wygnaniec z tego ziemskiego Raju” powraca do ogrodu, by ostatecznie upokorzyć się przed samym sobą, ale

${ }^{28}$ Federica Villa, Il cinema che serve. Giorgio Bassani cinematografico, Turyn: Edizioni Kaplan 2010, s. 200.

${ }^{29}$ Papież Celestyn V, który w 1294 roku zrzekł się urzędu i powrócił do życia eremity, przez Dantego umieszczony został w Piekle jako ten, „co z trwogi wielką skaził się odmową". Dante Alighieri, Boska komedia, tłum. Edward Porębowicz, Warszawa: Państwowy Instytut Wydawniczy 1990, s. 36. 
i wyzdrowieć z choroby miłości. W obu tych scenach autor zwraca uwagę czytelnika na padający cień, przy pierwszej próbie „głęboki cień zalatujący wonią pokrzyw i nieczystości”30, za drugim zaś razem „mleczne cienie" 31 skąpane w morzu mleka i srebra, w poświacie księżyca. Ta granica między światłem a mrokiem, nakładająca się na granicę wyznaczoną przez mur, stanowi jeden z tropów pozwalających interpretować przekroczenie progu ogrodu jako mitologiczne zejście do Hadesu. Oto główny bohater - Orfeusz schodzi do podziemnego królestwa umarłych - ogrodu, w którym przebywa jego towarzyszka, Micòl - Eurydyka. Sam autor podsuwał taki właśnie klucz odczytania, pisząc w swoim szkicu:

W powieści Micòl symbolizuje Życie i dlatego umiera, wybiera śmierć. Giorgio natomiast uosabia Sztukę; dlatego żyje, wybiera ocalenie, a tym samym pisanie ${ }^{32}$.

Eurydyka-Micòl nie zezwala pokochać się poecie, gdyż dar jej nieobecności umożliwi mu opiewanie tego, o czym nikt dotąd nie słyszał $^{33}$. Podobnie Orfeusz ze straty Eurydyki czerpał moc, by poświadczyć w pieśni ból istnienia i jedynie utraciwszy swoją ukochaną, mógł osiągnąć doskonałość w Sztuce. Na taką właśnie interpretację nie godził się Ugo Pirro, dając wyraz swojemu oburzeniu w przytaczanym wywiadzie, w którym uznał za niedopuszczalną i niegodną człowieka przewagę Sztuki nad Życiem ${ }^{34}$. Nad całą powieścią ciąży to, co „nie zaszło" między Micòl a głównym bohaterem, gdy skryli się przed deszczem w wozowni, ów nieskradziony pocałunek czy dotyk, ta chwila wahania, w której Giorgio nie wiedział jeszcze czy kocha, a która być może na zawsze zmieniła ich życie, niczym decyzja Orfeusza, aby obejrzeć się za siebie i utracić Eurydykę. W ekranizacji De Siki cały ten wątek, te podskórnie tętniące wątpliwości i niepewność zostały

\footnotetext{
${ }^{30}$ Giorgio Bassani, Ogród rodziny..., s. 55.

${ }^{31}$ Ibidem, s. 310.

32 Giorgio Bassani, Il giardino tradito, s. 320 (tłum. K. S.).

33 Por. Gianni Venturi, op. cit., s. 94.

${ }^{34}$ Enzo Magrì, op. cit., s. 79.
} 
usunięte, od początku filmu wiadomo bowiem, że Giorgio kocha się w Micòl, a kolejne retrospekcje z nastoletniego okresu ich życia jeszcze mocniej utwierdzają widza w tym przekonaniu. Świadome, ostateczne wyrzeknięcie się Micòl w kinowej wersji powieści przemienia się z kolei w jej prośbę, niewysłuchaną przez krnąbrnego bohatera.

\section{Tenis, Skiwasser i jazz}

Niebagatelną rolę dla poetyki powieści odgrywają przedmioty, które, jak zauważa Joanna Ugniewska, służą „zakotwiczeniu pamięci, stworzeniu swoistego kodu, szczególnego języka bogatego w aluzje, odniesienia, powiązane ze ścisłym kręgiem osób, osadzonym w dookreślonych realiach społecznych, pokoleniowych, (...) a nade wszystko czasowych"35. To maszyna do pisania Littoria, ulubiony napój Micòl - Skiwasser, papierosy Dunhill, oprawione zdjęcia, ale przede wszystkim rakiety do uprawianego bez wytchnienia tenisa oraz płyty z muzyką jazzową i klasyczną. W filmie poszukuje ich niestrudzenie oko kamery, której ruch Ennio Guarnieri zdynamizował częstym, dla dzisiejszego widza nieco natrętnym, użyciem zoomu (o wiele chętniej przezeń stosowanym niż „jazda”); raz po raz ujęcie kończy się jakimś detalem, czy choćby zbliżeniem na Jora, wywodzącego się z tak modnej podówczas rasy doga arlekina należącego do Finzi-Continich. Wspomniany tenis, tak w powieści i jej ekranizacji, jak i w życiu Bassaniego, pełnił rolę szczególną ${ }^{36}$. W dziele filmowym

${ }^{35}$ Joanna Ugniewska, Casa, giardino, cimitero - segni della separatezza sociale nel „Giardino dei Finzi Contini” di Giorgio Bassani, [w:] Scritture del Novecento - saggi e appunti, Warszawa: Katedra Italianistyki UW 2008, s. 35 (tłum. K. S.).

${ }^{36}$ Sekrety techniki tenisowej Giorgia Bassaniego i jego umiłowanie dla tej dyscypliny w krótkim szkicu omawia Gianni Clerici, zaprzyjaźniony z pisarzem włoski dziennikarz sportowy i tenisista, który odnotowuje m.in., że w powieści o grze w tenisa jest mowa bez mała trzydzieści trzy razy. Por. Gianni Clerici, Giorgio Bassani tennista, [w:] Giorgio Bassani - uno scrittore da ritrovare, red. Maria Ida Gaeta, Rzym: Edizioni Fahrenheit 451 2004, s. 167-170. 
i literackim to przy grze $w$ tenisa zawiązuje się akcja, to tenis jest pretekstem do spotkań bohaterów i otwarcia ogrodu dla obcych, przepustką do tego ziemskiego raju; wreszcie to zmagań na korcie dotyczy metafora, za pomocą której powieściowa Micòl chce ukazać narratorowi, jaki trud łączy się z miłością. Mówi on:

(...) bo ja... można powiedzieć, że byłem zawsze obok niej, a nie naprzeciw. A miłość (...) to sprawa między dwojgiem ludzi zdecydowanych zwyciężać się nawzajem: okrutny sport, niemiłosierny - o ileż brutalniejszy od tenisa! - sport, który nie wyklucza żadnych ciosów, a dobroć serca i uczciwość intencji nie wchodzą w ogóle w grę $(\ldots)^{37}$.

Tenis to także temat zastępczy, pozwalający nie myśleć, lub raczej udawać, że się nie myśli o sprawach bieżących: śmiertelnej chorobie Alberta i nieuchronnej zagładzie tego dawnego światka. Vittorio De Sica postanowił użyć go z kolei w zwieńczeniu filmu; oto $\mathrm{w}$ zwolnionym $\mathrm{w}$ takt pieśni rabina tempie obserwujemy grającą w tenisa młodzież, wszystkich tych, którzy na ekranie umarli: Micòl, Alberta, Giampiego Malnate i Bruno Lattesa. Ostatni kadr, na którym pojawiają się napisy końcowe, to pusty kort. Jak w wywiadzie wyznał kompozytor muzyki do filmu, syn reżysera, Manuel De $\mathrm{Sica}^{38}$, było to jedno $\mathrm{z}$ dwóch proponowanych zakończeń, alternatywne wobec widoków wyludnionej Ferrary i opustoszałego ogrodu, które ostatecznie znalazły się $\mathrm{w}$ finałowej sekwencji jedynie częściowo. Towarzyszy im, jak wspomniałam, przesycone głębokim smutkiem zawodzenie rabina, i to głównie ono, wraz z leitmotivem I'm getting sentimental over you, współczesną bohaterom kompozycją jazzową Tommy'ego Dorseya, tak chętnie nastawianą przez Micòl na gramofonie, pozostaje w pamięci, bardziej niż dość anonimowa, mająca charakter wypełniający muzyka De Siki, w 1973 roku jednakże uhonorowana nominacją do nagrody Grammy.

${ }^{37}$ Giorgio Bassani, Ogród rodziny..., s. 240.

${ }^{38}$ Wypowiedź Manuela De Siki zamieszczona w dodatkach do wydania DVD filmu OGRód Rodziny Finzi-Continich w serii Il grande cinema. 
W przytaczanym wywiadzie ${ }^{39}$ Manuel De Sica opowiada, jak jego ojciec, otrzymawszy propozycję nakręcenia ekranizacji Ogrodu rodziny Finzi-Continich od producenta Fausta Saraceniego, miał powiedzieć, że to bardziej temat dla Luchina Viscontiego lub może Maura Bologniniego. Widział w niej jednak możliwość powrotu do wielkiego kina (za ostatni swój dobry film uznawał nakręcony w 1956 roku DACH (Il tetto), nie wykazując szczególnego przywiązania nawet do późniejszej MATKI I CóRKI (La ciociara, 1960); mawiał, że od tamtej pory pracował jako „nauczyciel aktorstwa”, nie zaś „reżyser”) i dlatego też zgodził się na podjęcie tego wyzwania. „Co za piękny film!”, chciałoby się zawołać za narratorem powieści Giorgia Bassaniego, trawestując jego końcową konstatację ${ }^{40}$. Ale czy aby na pewno jest tak w istocie?

\footnotetext{
${ }^{39}$ Ibidem.

${ }^{40}$ Giorgio Bassani, Ogród rodziny..., s. 313.
} 